\title{
VANITAS ESPAÑOLES CON GAFAS
}

\author{
BARBÓN GARCÍA JJ ${ }^{1}$
}

La Vanitas Vanitatum expresa la representación alegórica de la vida humana mediante referencias iconográficas que ponen de relieve su fragilidad. En la época barroca, durante el s. XVII, conocida en España como el Siglo de Oro, los pintores crean multitud de cuadros sobre la vanitas hasta el punto de ser considerado un genero pictórico independiente. Estas imágenes, alusivas al desengaño y a la vanidad de las cosas terrenales, transmiten un mensaje moralizante sobre lo fugaz, miserable e insignificante de nuestra existencia. Los efímeros placeres mundanos, la belleza, la riqueza y el poder se contraponen de forma abrupta con la muerte, normalmente representada por una o varias calaveras, para advertirnos sobre la condición pasajera de la vida y la necesidad de practicar la virtud.
La gafa es utilizada dentro de la vanitas como objeto ligado a la lectura y al cultivo del saber, es decir, en su papel de motivo simbólico que representa la inutilidad de la vida intelectual y del saber científico. Otros elementos admonitorios que configuran la simbología de la vanitas van a ser los relojes, las flores, las joyas y otros objetos lujosos, monedas, libros, espejos, armas, etc. Los libros profanos expresan, además, la inconveniencia de un conocimiento excesivo que en nada beneficia al espíritu cristiano.

Alonso Gutiérrez, pintor madrileño del s. XVII, asocia las gafas en su Vanitas a unos libros viejos con los bordes doblados y gastados, a un tampón y a tres plumas de ave para escribir como alusiones conjuntas al absurdo del conocimiento y del

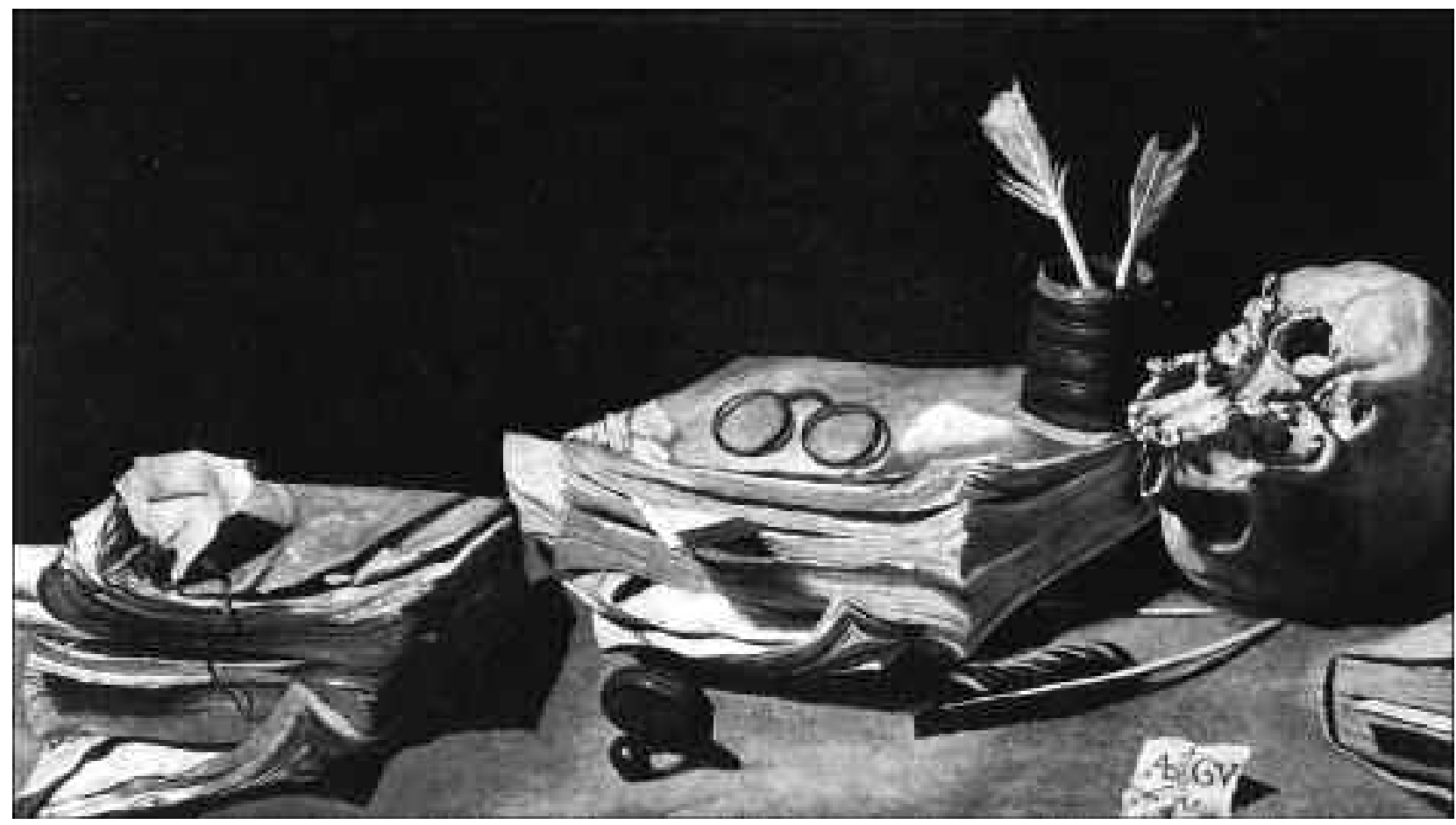

Vanitas de Alonso Gutiérrez. Colección Particular. Madrid.

\footnotetext{
1 Oftalmólogo. Hospital San Agustín de Avilés. Asturias. España.

E-mail: jjbarbon@telecable.es
} 


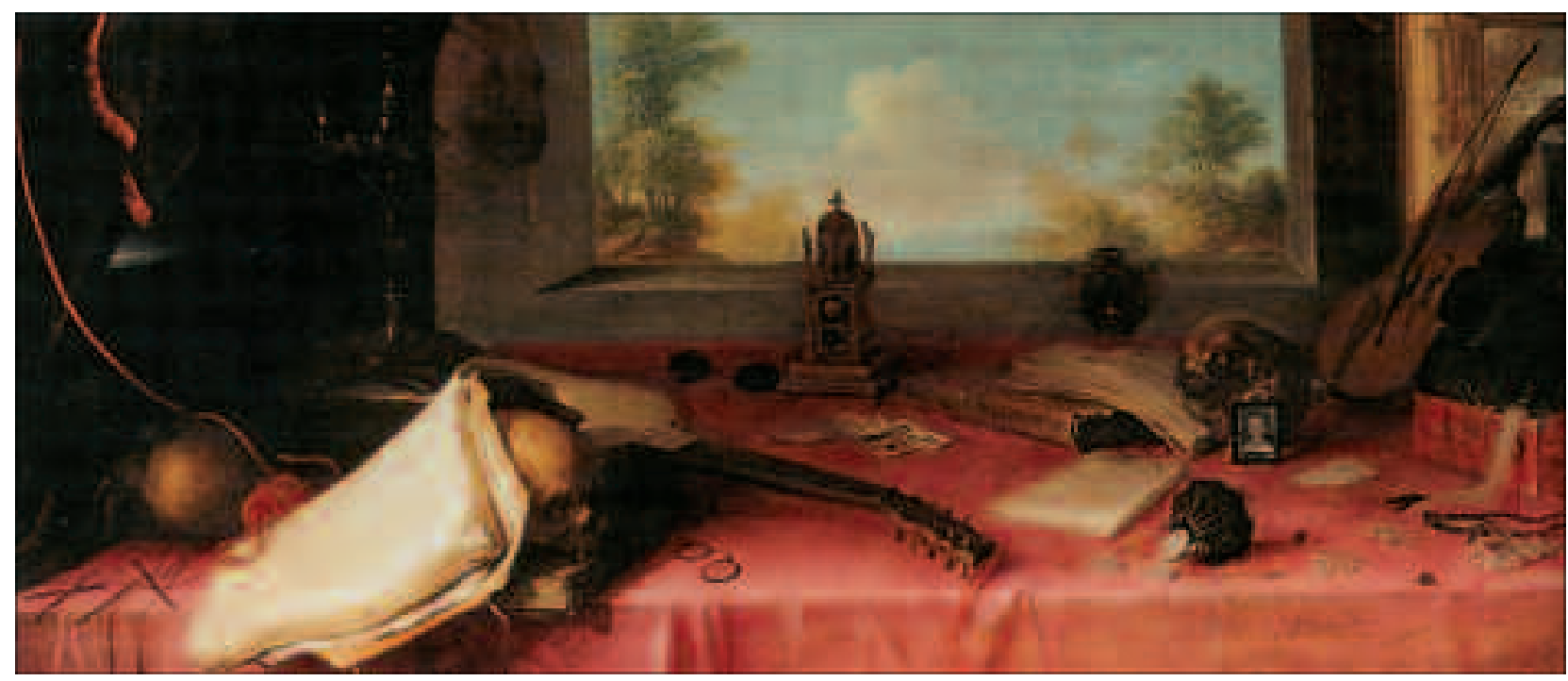

Vanitas atribuido a Andrés Deleito. Colección Particular. Londres.

estudio. Otro lienzo, atribuido a Andrés Deleito, compone una referencia a la vanidad de los placeres con multitud de objetos alusivos a los cinco sentidos, entre ellos unas gafas. En ambos casos, la calavera es el contrapunto contundente que señala la implacable temporalidad de la existencia humana.

\section{BIBLIOGRAFÍA}

- Valdivieso E. Vanidades y desengaños en la pintura española del Siglo de Oro. Madrid: Fundación de Apoyo a la Historia del Arte Hispánico; 2002.

- Battistini M. Símbolos y alegorías (Los Diccionarios del Arte). Barcelona: Electa; 2003

- Zuffi S. La naturaleza muerta. Milán: Ed. Electa; 1999. 